[Agr. Biol. Chem.. Vol. 30, No. 7, p. 703 705, 1966]

\title{
Guanosine Formation from Guanine by Bacillus licheniformis
}

\author{
By Isao TAKEDA, Tadaaki Ooka and Shiro Hayakawa \\ Technical Research Laboratory, Asahi Chemical Industry, Co., Ltd. \\ Nakadaicho, Itabashi-ku, Tokyo \\ Received January 22, 1966
}

\begin{abstract}
Adenine-auxotrophic mutant of Bacillus licheniformis formed considerable amount of guanosine from guanine. The guanosine formation was stimulated by the addition of penicillin to the growing cells and by the presence of uridine in the crude extract. The crude extract preserved for long time showed the changes of the enzyme actions for added guanine.
\end{abstract}

It has been reported that auxotrophic mutants excrete purine and pyrimidine derivatives in their fluids ${ }^{1-4)}$ and some auxotrophic mutants of Bacillus subtilis also accumulate adenosine in high yield in the addition of adenine. $^{5)}$ The conversion of purine bases into their nucleosides by the same auxotroph has been known. ${ }^{6}$

The authors have studied on the formation of guanosine from guanine by the adenine auxotroph derived from Bacillus licheniformis ATCG 10716. Bacillus licheniformis ATCC 10716 was obtained from Dr. K. Sugawara, Ibaragi University, to whom we express our gratitude.

This auxtroph was incubated in the medium composed of $5 \%$ glucose, $0.1 \% \mathrm{KH}_{2} \mathrm{PO}_{4}, 0.1 \%$ $\mathrm{K}_{2} \mathrm{HPO}_{4}, \quad 0.05 \% \quad \mathrm{MgSO}_{4} \cdot 7 \mathrm{H}_{2} \mathrm{O}, 0.4 \%$ urea, $1.0 \%$ yeast extract and $2 \mathrm{mg} \%$ adenine in respective final concentration, the $\mathrm{pH}$ of which was adjusted to 7.0 by $\mathrm{NaOH}$. This was cultured at $35^{\circ} \mathrm{C}$ on reciprocal shaker with $70 \mathrm{ml}$ of medium in $500 \mathrm{ml}$ flasks. After 24

1) B. Magasanik and M.S. Brooke, J. Biol. Chem., 206, 83 (1954).

2) E. G. Gollub and J.S. Gots, J. Bacteriol., 78, 320 (1959).

3) K. Uchida, A. Kuninaka, H. Yoshino and M. Kibi,

This Journal, 25, 804 (1961).

4) R. Aoki, N. Muramatsu and Y. Tsuchiya, Amino Acid and Nucleic Acid, 8, 131 (1963).

5) Y. Koaze, Y. Yamada, M. Kojima and T. Hara, This Journal, 26, 740 (1962).

6) A. Yamanoi, Y. Hirose, M. Aoki and T. Shiro, The Nucleic Acid Symposium on November 7, 1965, in Osaka.

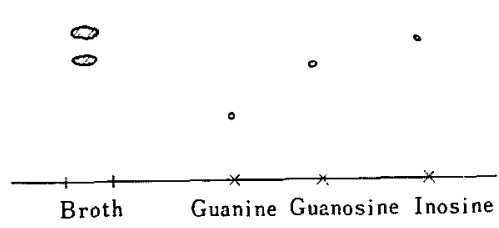

FIG. 1. Guanosine Formation from Guanine by Bacillus licheniformis (ad-).

Cells were incubated as described in the text and centrifuged off. Aliquots of the supernatant were subjected to paperchromatography and developed with a solvent system of saturated ammonium sulfate:isopropyl alcohol: water $(79: 2: 19)$.

hours, $105 \mathrm{mg}$ of guanine (final concentration $150 \mathrm{mg} \%$ ) and $1.4 \mathrm{~g}$ of sterilized $\mathrm{CaCO}_{3}$ per flask were added, and culture was continued further for 30 hours. Fig. 1 shows the formations of inosine and guanosine from guanine. Cells were centrifuged off at 3000 r.p.m. Inosine and guanosine formed in the culture fluids were identified by the paperchromatograms and their ultraviolet spectra. Inosine and guanosine formed were separated from culture fluids with the ion-exchange column chromatography of Dowex-1-Cl. Conversion ratio of guanosine from added guanine was about $25 \%$. In the absence of guanine, guanosine was not detected in the culture fluids and inosine formation was shown by the addition of labelled guanine. The formation of guanosine by this auxotroph reached to the 
maximal value under suboptimal condition of adenine or yeast extract for growth. Such result may be explained by the weak nucleosidase activity of cells under above condition.

Effects of some compounds were studied

\section{TABle I. EFFECts of PENicillin AND SOdium Azide on Guanosine Formation}

Compounds added Growth Guanosine formed

$\begin{array}{llcr}\text { Penicillin } & 2000 \mathrm{IU} / \mathrm{ml} & \mathrm{W} & 109 \\ \mathrm{NaN}_{3} & 10^{-3} \mathrm{M} & + & 34 \\ - & & \mathrm{W} & 69\end{array}$

These sterile compounds were added at the same time as the supplementation of $150 \mathrm{mg} \%$ of guanine. Growth was estimated by measuring the turbidity of the culture fluids using a spectrophotometer at the wave length of $600 \mathrm{~m} \mu$. Guanosine was assayed by the auxotrophic guanineless mutant, strain P-14, of Aerobacter aerogenes ${ }^{1)}$ after the elution with water from the paperchromatogram.

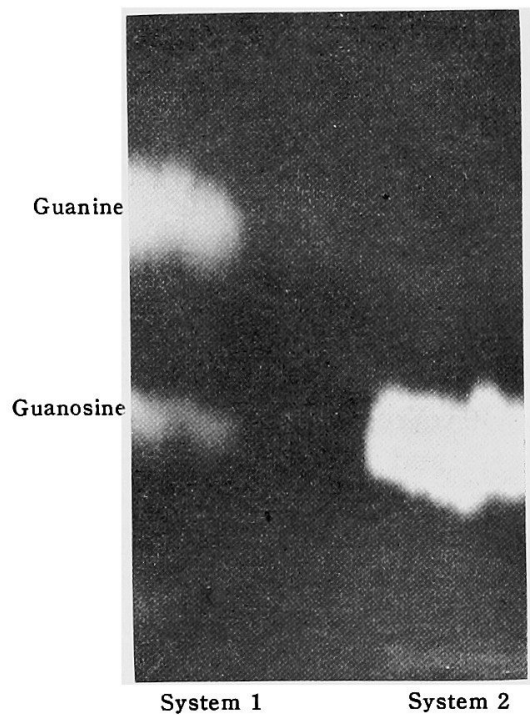

FIG. 2. Autoradiogram for the Guanosine Formation from Labelled Guanine by Crude Extract.

Cells were cultured for 24 hours and crude extracts were prepared as described in the text. Reaction mixtures contained $1 \mathrm{ml}$ of crude extract $(5.7 \mathrm{mg}$ as protein $), 1.0 \mu \mathrm{C}$ of 8-C14-guanine- $\mathrm{HCl}$ in reaction system 1 and further $10 \mu$ moles of uridine in reaction system 2 . To both of them were added $5 \mu$ moles of phosphate and $\mathrm{MgSO}_{4} \cdot 7 \mathrm{H}_{2} \mathrm{O}$ in a total volume of $1.5 \mathrm{ml}$ with $0.1 \mathrm{M}$ Tris-HCl buffer ( $\mathrm{pH}$ 7.3). Incubated for 5 hours at $37^{\circ} \mathrm{C}$. After incubation, reactions were stopped by the addition of uranyl reagent. Aliquots of the supernatant $(0.1 \mathrm{ml})$ were subjected to paperchromatography and developed with $n$-butanol : acetic acid : water $(4: 1: 1)$ on the guanosine formation from guanine under the same condition. Table I shows that penicillin stimulates the guanosine formation. Sodium azide inhibited the conversion of guanosine formed to inosine.

This mutant was cultured at $30^{\circ} \mathrm{C}$ on reciprocal shaker by the same method as men-

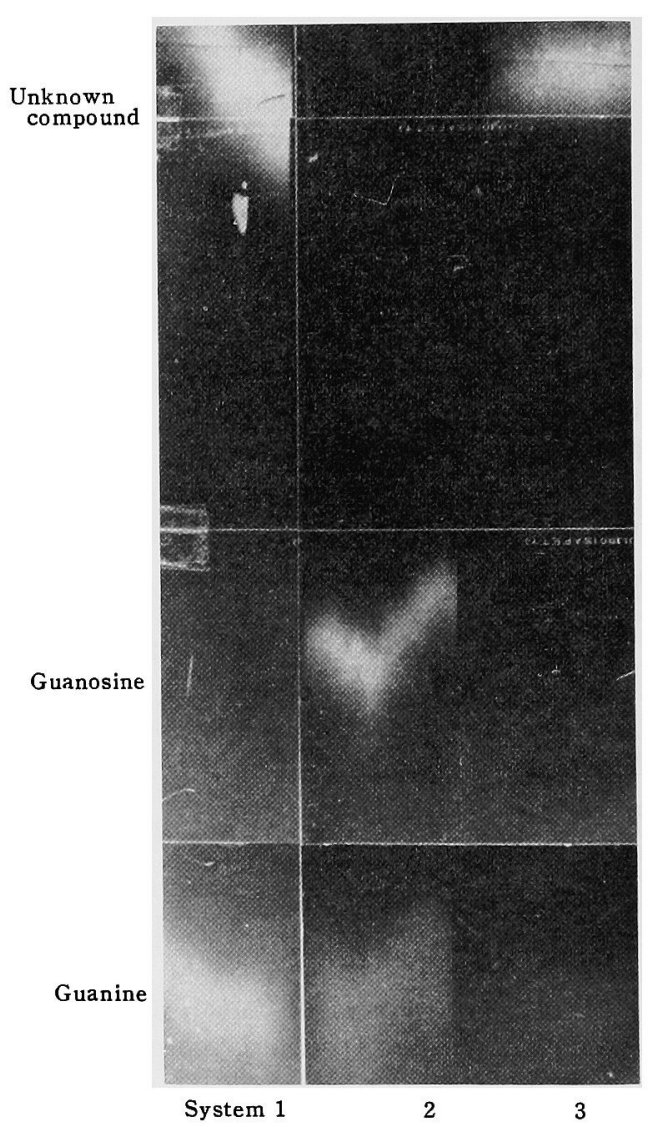

FIG. 3. Autoradiogram for the Conversion of Labelled Guanine by Preserved Crude Extract.

Crude extracts used in Fig. 2 were treated as described in the text. Reaction system 1 contained $1 \mathrm{ml}$ of extrnct (1.8 $\mathrm{mg}$ as protein) and $1.0 \mu \mathrm{C}$ of $8-\mathrm{C}^{14}$-guanine- $\mathrm{HCl}$. Reaction system 2 was added with $10 \mu$ moles of uridine to system 1 and system 3 with $10 \mu$ moles of ATP and ribose5 -phosphate to system 1 in a total volume of $1.5 \mathrm{ml}$ with $0.1 \mathrm{M}$ Tris- $\mathrm{HCl}$ buffer ( $\mathrm{pH}$ 7.3). To all reaction mixtures were added $5 \mu$ moles of phosphare and $\mathrm{MgSO}_{4} \cdot 7 \mathrm{H}_{2} \mathrm{O}$ in $1.5 \mathrm{ml}$. Aliquots of reactions $(0.05 \mathrm{ml}$ were paperchromatographed with saturated ammonium sulfate: isopropyl alcohol: water $(79: 2: 19)$. 
tioned above. Cells were gathered after 24 hours incubation and washed with $0.05 \mathrm{M}$ Tris$\mathrm{HCl}$ buffer at $\mathrm{pH}$ 7.3. These cells were sonicated for 15 mins in $0.1 \mathrm{~m}$ Tris-HCl buffer of pH 7.3 and centrifuged off at 10,000 r.p.m. The supernatant fluid was dialyzed against $0.01 \mathrm{~m}$ Tris-HCl buffer of $\mathrm{pH} 7.3$ for 12 hours at $0^{\circ} \mathrm{C}$. This crude extract of $1.0 \mathrm{ml}(5.7 \mathrm{mg}$ as protein) and $1 \mu \mathrm{C}$ of $8-\mathrm{C}^{14}$-guanine-HCl (specific activity, $13.9 \mu \mathrm{C}$ per $\mathrm{mg}$ ) were incubated for 5 hours at $37^{\circ} \mathrm{C}$. Guanine was incorporated only into guanosine by the cell-free extract of this mutant as shown in Fig. 2. By the addition of uridine, the conversion of guanine to guanosine was stimulated. Such result shows the presences of the nucleoside-N-ri bosyl group transfer reactions between nucleosides and guanine, which have been reported by Ogata et al. ${ }^{7)}$ The above crude extract was preserved for 10 days in refrigerator at $-7^{\circ} \mathrm{C}$ and dialyzed against $0.01 \mathrm{~m}$ Tris- $\mathrm{HCl}$ buffer of $\mathrm{pH} 7.3$ for 20 hours at $0^{\circ} \mathrm{C}$. The precipitate formed was discarded after centrifuging at $5000 \mathrm{r} . \mathrm{p} . \mathrm{m}$. This extract of $1.0 \mathrm{ml}(1.8 \mathrm{mg}$ as protein) and $1 \mu \mathrm{C}$ of $8-\mathrm{C}^{14}$-guanine- $\mathrm{HCl}$ were incubated for 8 hours at $37^{\circ} \mathrm{C}$. After incubation, reactions were stopped by the addition of uranyl reagent and the precipitate

7) T. Sakai, T. Tochikura and K. Ogata, This Journal, 29, 742 (1965). was discarded after centrifuging. Reaction mixtures were adjusted to $\mathrm{pH} 7.0$ with $2 \mathrm{~N}$ $\mathrm{KOH}$ and a small amount of them was paperchromatographed. In the reaction system of guanine and cell-free extract (system 1 of Fig. 3), all guanine added was converted into unknown compound. This unknown compound was not formed at any condition in Fig. 2. The addition of uridine to the reaction system 1 showed small amount of guanosine formation from guanine (system 2), but the addition of ATP and ribose-5-phosphate did not lead to form guanosine (system 3). The formation of unknown compound was inhibited in the presence of uridine (system 2). This unknown compound formed in the reaction systems 1 and 3 was stable in heating for 60 mins at $80^{\circ} \mathrm{C}$ under acid ( $\mathrm{pH} \mathrm{2)}$ or alkaline condition ( $\mathrm{pH} \mathrm{12).} \mathrm{It} \mathrm{is} \mathrm{not} \mathrm{clear}$ about the reasons why such differences between Figs. 2 and 3 were observed, but these phenomena may explain the changes of enzyme activities or actions under the storage and dialysis of enzymes.

The authors wish to express their thanks to Director Dr. A. Suzuki and Dr. M. Murakoshi of this laboratory for the interest and encouragement during the course of this work. 